\title{
Biodiversity of Natural Enemies of Pseudococcidae in the Semiarid Region of Brazil
}

\author{
Maria G. R. Sá ${ }^{1}$ José E. M. Oliveira ${ }^{2}$, Valmir A. Costa $^{3} \&$ Paulo R. C. Lopes ${ }^{2}$ \\ ${ }^{1}$ Agricultural Sciences Campus, Federal University of São Francisco Valley, Petrolina, Pernambuco State, Brazil \\ ${ }^{2}$ Embrapa Semiárido, Petrolina State, Brazil \\ ${ }^{3}$ Biological Institute, Campinas, São Paulo, Brazil \\ Correspondence: Maria G. R. Sá, Agricultural Sciences Campus, Federal University of São Francisco Valley, \\ Highway BR 407, 12 Lot 543, Nilo Coelho Irrigation Project, S/N C1, Petrolina, Pernambuco State, Brazil. Tel: \\ 55-87-99618-4185. E-mail: mariarosa.eags@hotmail.com
}

Received: February 10, 2020

Accepted: May 4, $2020 \quad$ Online Published: June 15, 2020

doi:10.5539/jas.v12n7p24

URL: https://doi.org/10.5539/jas.v12n7p24

\begin{abstract}
Pseudococcidae species, also known as mealybugs, comprises a complex of pests in various cultivated and non-cultivated plant species, among which fruit plants are most affected by both direct and indirect damage. The incidence of these pest species has been constant in productive environments, causing significant losses due to sap suction, virus transmission, and damage to fruit quality. Thus, this study aimed to know and investigate the population dynamics of natural enemies of Pseudococcidae in different fruit plants cultivated in the semiarid region of Brazil. For this, mealybugs associated with roots, stems, leaves, and fruits of vine, pear, apple, persimmon, guava, and acerola trees were collected biweekly in 14 properties in the São Francisco Valley region, from July 2016 to June 2017. These mealybugs were properly separated for the removal of their predators and the emergence of parasitoids associated with them (Pseudococcidae). Coccophagus sp., Aenasius sp., Anagyrus kamali, Anagyrus sp. 1, Anagyrus sp. 2, Anagyrus sp. 3, Anagyrus sp. 4, Coccidoxenoides perminutus, Gyranusoidea indica, Leptomastix dactylopii, Prochiloneurus sp., Aprostocetus sp., and Signiphora sp. were identified as parasitoids and Diadiplosis multifila, Cryptolaemus montrouzieri, Tenuisvalvae notata, Cycloneda sanguinea, and Hippodamia convergens were identified as predators, in addition to unidentified species of Coccinellidae and Chrysopidae.
\end{abstract}

Keywords: biological control, fruit farming, parasitoids, plant protection, predators

\section{Introduction}

In Brazil, tropical fruit production is concentrated in the northeast region, which has a predominantly semiarid climate (Araújo, Fernandes, Silva, Ferreira, \& Costa, 2015). This region exports a large part of its production, which leads to phytosanitary management necessary to ensure the quality of the products. Mealybugs (Hemiptera: Pseudococcidae) are agricultural pests responsible for a significant reduction in plant productivity and are easily spread through the international fruit trade due to their small size and rapid fixation on plant surfaces (Beltrà et al., 2015). They can feed on all parts of the plant, but the aerial part is most affected by them. When feeding, mealybugs produce honeydew, which is a carbohydrate substance that favors the fumagina proliferation and, consequently, depreciates the qualitative and quantitative value of fruits, directly affecting their commercialization (Bostanian, Vincent, \& Isaacs, 2012; Bertin, Bortoli, Botton, \& Parra, 2013).

Encyrtidae comprises one of the most efficient families of parasitoids for controlling mealybug species. Biological control of Pseudococcidae using these natural enemies has been applied in several regions around the world, with successful results (Tena, Nieves, Herrero, \& Urbaneja, 2017), such as the use of Acerophagus sp. and Leptomastix sp. to control Phenacoccus peruvianus Granara de Willink, Phenacoccus herreni Cox \& Williams, and Paracoccus marginatus Williams and Granara de Willink (1992). Anagyrus is a genus of parasitoids of Planococcus citri Risso (1813) and Planococcus ficus Signoret (1875) (Beltrà et al., 2015) and has been one of the most studied for the control of Pseudococcidae, especially in South America (Bugila, Franco, Silva, \& Branco, 2014). Coccidoxenoides perminutus Girault (1915) (Hymenoptera: Encyrtidae) is an example 
of a parasitoid recently found in the São Francisco Valley, parasitizing all instars of $P$. citri (Fernades, Oliveira, Costa, \& Menezes, 2016), with potential for biological control of this pest (Menezes et al., 2017).

The use of natural enemies is one of the best ways to control Pseudococcidae. However, it is necessary to know all the organisms involved so that they act satisfactorily in the management (Lima, Melo, \& Barros, 2016). Thus, this study aimed to know and investigate the biodiversity of natural enemies of Pseudococcidae in fruit plants in the São Francisco Valley, semiarid region of Brazil.

\section{Material and Methods}

For the identification of natural enemy species of Pseudococcidae, mealybugs associated with vine, pear, apple, persimmon, guava and acerola crops were collected in different farms in the São Francisco Valley, semiarid region of Pernambuco, Brazil. Ten plants were analyzed per hectare for each crop. The plants were selected at random in order not to induce the choice of plants affected or not by scale insects. The study was conducted between July 2016 and June 2017. The observations and collections were performed from roots, stems, leaves, and fruits. Mealybugs and plant material were collected biweekly using pruning shears and fine bristle brush. Afterward, they were immediately sent to Embrapa Semiárido Entomology Laboratory, Petrolina, Pernambuco, Brazil (with geographical coordinates of $09^{\circ} 04^{\prime} 16.4^{\prime \prime} \mathrm{S}, 40^{\circ} 19^{\prime} 5.37^{\prime \prime} \mathrm{W}$ and altitude of $379 \mathrm{~m}$ ).

The mealybugs mummified, together with their origin food, were kept in polypropylene jars capped with voile fabric for a week until the emergence of the parasitoids. Those emerged were placed in labeled Eppendorf tubes containing 70\% alcohol and then sent for identification in the Biological Institute, in São Paulo. Predator insects were also found in the mealybug colonies, which were collected manually with the support of a fine bristle paint-brush number 0, avoiding damage to insects, identified and individualized in Eppendorf tubes also containing $70 \%$ alcohol. These parasitoids and predators were kept under refrigeration. Population fluctuation was determined according to the number of parasitoids and predators found in the collected material.

Faunistic analysis was performed using frequency indices $(\mathrm{LF}=$ less frequent, $\mathrm{F}=$ frequent, $\mathrm{VF}=$ very frequent and $\mathrm{SF}=$ super frequent $)$, constancy $(\mathrm{Z}=$ accidental, $\mathrm{Y}=$ accessory and $\mathrm{W}=$ constant $)$, dominance $(\mathrm{ND}=$ non-dominant, $\mathrm{D}=$ dominant and $\mathrm{SD}=$ superdominant $)$, and abundance $(\mathrm{R}=$ rare, $\mathrm{D}=$ dispersed, $\mathrm{C}=$ common, $\mathrm{A}=$ abundant, $\mathrm{VA}=$ very abundant and $\mathrm{SA}=$ superabundant), proposed by Silveira Neto, Nakano, Barbin, and Villa Nova (1976) and made using the software for faunal analysis-AnaFau. The parasitoids were identified according to Woolley (1997) for Aphelinidae, Noyes (1980), and Noyes and Hayat (1994) for Encyrtidae, Schauff (1997) for Eulophidae, Darling (1997) for Perilampidae, Bouček and Heydon (1997), and Rueda and Axtell (1985) for Pteromalidae, and Woolley (1997) for Signiphoridae.

Entomological identification keys were used to identify insects. These keys are specific and were described by the Biological Institute in the analyzes carried out. The specimens were deposited in the "Oscar Monte" Entomophagous Insect Collection (IB-CBE) of the Biological Institute (Campinas, São Paulo, Brazil), under reference number IB-CBE-726. The applied indices (Dominance, abundance, frequency and constancy) are exposed and detailed in the results tables.

\section{Results}

Thirteen parasitoid species associated with Pseudococcidae were found in different cultures and locations in the São Francisco Valley. Coccophagus sp., a genus of parasitic species of Coccidae and Pseudococcidae (Woolley, 1997), Aenasius sp., Anagyrus kamali Moursi (1948), four other species of the genus Anagyrus, Coccidoxenoides perminutus Girault (1915), Gyranusoidea indica Shafee, Alam \& Agarwal 1975, Howard, Prochiloneurus sp., Aprostocetus sp., and Signiphora sp. Noyes (2017) show details on the distribution and hosts of parasitoids identified at species level, and Noyes (1980) show details on those identified at genus level, indicating that some of these are related to Pseudococcidae, such as Aenasius, Anagyrus, and Prochiloneurus. A. kamali was classified as a superdominant, superabundant and super frequent parasitoid and as one of the most constant. Anagyrus sp. 1, C. perminutus, Leptomastix dactylopii, and Aprostocetus sp. were the most expressive species in this study, after $A$. kamali (Table 1). Predators were numerically less expressive than parasitoids regarding the total number of natural enemies of mealybugs. The predatory fly, Diadiplosis multifila Felt (1907) (Diptera: Cecidomyiidae), was the most expressive natural enemy found in the sampled material, followed by Chrysopidae species and the ladybug, Cryptolaemus montrouzieri Mulsant (Coleoptera: Coccinellidae) (Table 1). 
Table 1. Faunistic analysis of parasitoids and predators of mealybug in the Submedio of the São Francisco Valley, Pernambuco, Brazil

\begin{tabular}{|c|c|c|c|c|c|}
\hline Natural Enemies & No. ind. & Dominance & Abundance & Frequency & Constancy \\
\hline \multicolumn{6}{|l|}{ Parasitoids } \\
\hline Coccophagus sp. & 2 & ND & $\mathrm{D}^{1}$ & LF & $\mathrm{Z}$ \\
\hline Aenasius sp. & 2 & ND & $\mathrm{D}^{1}$ & LF & $\mathrm{Y}$ \\
\hline Anagyrus kamali & 86 & SD & SA & $\mathrm{SF}$ & $\mathrm{W}$ \\
\hline Anagyrus sp. 1 & 40 & $\mathrm{D}$ & VA & VF & $\mathrm{Z}$ \\
\hline Anagyrus sp. 2 & 1 & ND & $\mathrm{D}^{1}$ & LF & $\mathrm{Z}$ \\
\hline Anagyrus sp. 3 & 4 & ND & $\mathrm{C}$ & $\mathrm{F}$ & $\mathrm{Z}$ \\
\hline Anagyrus sp. 4 & 1 & ND & $\mathrm{D}^{1}$ & LF & $\mathrm{Z}$ \\
\hline Coccidoxenoides perminutus & 24 & $\mathrm{D}$ & VA & VF & $\mathrm{W}$ \\
\hline Gyranusoidea indica & 4 & ND & $\mathrm{C}$ & $\mathrm{F}$ & $\mathrm{Y}$ \\
\hline Leptomastix dactylopii & 12 & $\mathrm{D}$ & $\mathrm{C}$ & $\mathrm{F}$ & $\mathrm{Y}$ \\
\hline Prochiloneurus sp. & 1 & ND & $\mathrm{D}^{1}$ & LF & $\mathrm{Z}$ \\
\hline Aprostocetus sp. & 19 & $\mathrm{D}$ & VA & VF & $\mathrm{W}$ \\
\hline Signiphora sp. & 5 & ND & $\mathrm{C}$ & $\mathrm{F}$ & $\mathrm{W}$ \\
\hline \multicolumn{6}{|l|}{ Predators } \\
\hline Diadiplosis multifila & 79 & SD & SA & $\mathrm{SF}$ & $\mathrm{W}$ \\
\hline Cryptolaemus montrouzieri & 18 & $\mathrm{D}$ & VA & $\mathrm{VF}$ & $\mathrm{Y}$ \\
\hline Tenuisvalvae notata & 1 & ND & $\mathrm{C}$ & $\mathrm{F}$ & $\mathrm{Y}$ \\
\hline Cycloneda sanguinea & 2 & ND & $\mathrm{C}$ & $\mathrm{F}$ & $\mathrm{Y}$ \\
\hline Hippodamia convergens & 3 & ND & $\mathrm{C}$ & $\mathrm{F}$ & $\mathrm{Y}$ \\
\hline
\end{tabular}

Note. No. ind.: number of individuals. ND: non-dominant, D: dominant, SD: superdominant; $\mathrm{D}^{1}$ : dispersed, SA: superabundant, VA: very abundant, C: common; SF: super frequent, VF: very frequent, F: frequent, LF: less frequent; Z: accidental, Y: accessory, W: constant.

Regarding the crops where these natural enemies were found associated with mealybugs, Anagyrus sp. 1 had the highest dominance, abundance, frequency and constancy, followed by L. dactylopii in vine. In this culture, the predatory fly $(D$. multifila) was the most frequent and constant natural enemy found in the sampled material, followed by Chrysopidae species and the ladybug (C. montrouzieri). The parasitoid A. kamali and chrysopid predators were the most prominent in pear trees. The parasitoids were found in a smaller number in persimmon trees, with higher prominence for the predatory fly (D. multifila). C. perminutus was dominant, very abundant, very frequent and constant in apple trees; no predators associated with this culture were found and no predators and parasitoids were found in guava and acerola trees (Table 2). 
Table 2. Faunistic analysis of parasitoids and predators of mealybug in different crops in the São Francisco Valley, Pernambuco, Brazil

\begin{tabular}{|c|c|c|c|c|c|c|}
\hline Culture & Natural Enemies & No. ind. & Do. & Ab. & Fr. & Con. \\
\hline \multicolumn{7}{|l|}{ Parasitoids } \\
\hline \multirow{7}{*}{ Vine } & Anagyrus kamali & 6 & $\mathrm{D}$ & $\mathrm{C}$ & $\mathrm{F}$ & $\mathrm{Y}$ \\
\hline & Anagyrus sp. 1 & 40 & $\mathrm{SD}$ & $\mathrm{SA}$ & $\mathrm{SF}$ & $\mathrm{W}$ \\
\hline & Leptomastix dactylopii & 11 & $\mathrm{D}$ & VA & $\mathrm{VF}$ & W \\
\hline & Aprostocetus sp. & 7 & $\mathrm{D}$ & $\mathrm{C}$ & $\mathrm{F}$ & $\mathrm{Y}$ \\
\hline & Pachycrepoideus vindemmiae & 6 & $\mathrm{D}$ & $\mathrm{C}$ & $\mathrm{F}$ & $\mathrm{Y}$ \\
\hline & Signiphora sp. & 1 & ND & $\mathrm{R}$ & $\mathrm{LF}$ & $\mathrm{Z}$ \\
\hline & Aphelinus sp. & 1 & ND & $\mathrm{R}$ & $\mathrm{LF}$ & $\mathrm{Z}$ \\
\hline \multirow{9}{*}{ Pear } & Bethylidae & 1 & ND & $\mathrm{C}$ & $\mathrm{F}$ & Z \\
\hline & Aprostocetus sp. & 6 & $\mathrm{D}$ & VA & $\mathrm{VF}$ & $\mathrm{Y}$ \\
\hline & Anagyrus kamali & 29 & $\mathrm{SD}$ & SA & $\mathrm{SF}$ & W \\
\hline & Signiphora sp. & 2 & ND & $\mathrm{C}$ & $\mathrm{F}$ & $\mathrm{Z}$ \\
\hline & Gyranusoidea indica & 2 & ND & $\mathrm{C}$ & $\mathrm{F}$ & Z \\
\hline & Encyrtidae & 1 & ND & $\mathrm{C}$ & $\mathrm{F}$ & $\mathrm{Z}$ \\
\hline & Anagyrus sp. 2 & 1 & ND & $\mathrm{C}$ & $\mathrm{F}$ & $\mathrm{Z}$ \\
\hline & Prochiloneurus sp. & 1 & ND & $\mathrm{C}$ & $\mathrm{F}$ & $\mathrm{Z}$ \\
\hline & Coccidoxenoides perminutus & 2 & ND & $\mathrm{C}$ & $\mathrm{F}$ & $\mathrm{Z}$ \\
\hline \multirow{3}{*}{ Apple } & Aprostocetus sp. & 3 & ND & VA & $\mathrm{F}$ & $\mathrm{Y}$ \\
\hline & Coccidoxenoides perminutus & 16 & $\mathrm{D}$ & VA & $\mathrm{VF}$ & W \\
\hline & Gyranusoidea indica & 1 & ND & VA & $\mathrm{F}$ & Z \\
\hline \multirow{9}{*}{ Persimmon } & Aenasius sp. & 1 & ND & $\mathrm{D}$ & $\mathrm{LF}$ & Z \\
\hline & Coccidoxenoides perminutus & 3 & ND & A & $\mathrm{VF}$ & W \\
\hline & Aprostocetus sp. & 1 & ND & $\mathrm{D}$ & $\mathrm{LF}$ & $\mathrm{Z}$ \\
\hline & Coccophagus sp. & 2 & ND & $\mathrm{C}$ & $\mathrm{F}$ & $\mathrm{Y}$ \\
\hline & Perilampus sp. & 1 & ND & $\mathrm{D}$ & $\mathrm{LF}$ & $\mathrm{Z}$ \\
\hline & Signiphora sp. & 1 & ND & $\mathrm{D}$ & $\mathrm{LF}$ & $\mathrm{Z}$ \\
\hline & Anagyrus kamali & 4 & ND & VA & $\mathrm{VF}$ & W \\
\hline & Gyranusoidea indica & 1 & ND & $\mathrm{D}$ & $\mathrm{LF}$ & $\mathrm{Z}$ \\
\hline & Anagyrus sp. 3 & 4 & ND & VA & $\mathrm{VF}$ & W \\
\hline \multicolumn{7}{|l|}{ Predators } \\
\hline \multirow{4}{*}{ Vine } & Diadiplosis multifila & 61 & $\mathrm{D}$ & VA & $\mathrm{VF}$ & W \\
\hline & Cryptolaemus montrouzieri & 15 & $\mathrm{D}$ & VA & $\mathrm{F}$ & $\mathrm{Y}$ \\
\hline & Tenuisvalvae notata & 1 & ND & VA & $\mathrm{F}$ & $\mathrm{Z}$ \\
\hline & Cycloneda sanguinea & 2 & ND & VA & F & $\mathrm{Z}$ \\
\hline \multirow{3}{*}{ Pear } & Diadiplosis multifila & 1 & ND & $\mathrm{R}$ & $\mathrm{LF}$ & $\mathrm{Y}$ \\
\hline & Cryptolaemus montrouzieri & 3 & ND & $\mathrm{C}$ & $\mathrm{F}$ & $\mathrm{Y}$ \\
\hline & Hippodamia convergens & 3 & ND & $\mathrm{C}$ & $\mathrm{F}$ & Y \\
\hline Persimmon & Diadiplosis multifila & 17 & $\mathrm{D}$ & VA & $\mathrm{F}$ & $\mathrm{W}$ \\
\hline
\end{tabular}

Note. No. ind.: number of individuals. Do.: dominance; Ab.: abundance; Fr.: frequency; Con.: constancy. ND: non-dominant, D: dominant, SD: superdominant; $\mathrm{D}^{1}$ : dispersed, A: abundant, SA: superabundant, VA: very abundant, C: common; R: rare; SF: super frequent, VF: very frequent, F: frequent, LF: less frequent; Z: accidental, Y: accessory, W: constant.

With regard to parasitoids of mealybugs, persimmon trees had the highest number of these natural enemies, with peaks of 106 and 98 individuals per collection, found in most of the collections performed. The pear trees (178 parasitoids collected) had a uniform distribution over time with a low number of insects, except for the population peaks of 68 and 31 individuals per collection. The apple trees and vine had a low number of parasitoids (Figure 1). There was a higher number of parasitoids in crops subjected to less phytosanitary treatments, such as persimmon and pear trees, unlike the vine, which is subjected to constant applications of products for the control of various pests and diseases, which may affect the development of these beneficial organisms. The number of predators was less expressive than that of parasitoids throughout the experimental 
period and in all cultures, considering the highest population peak of 14 individuals (Figure 2). This is related to predators' independence on their prey, i.e., they do not need to be directly associated with the insect, differently from parasitoids, which need to complete their cycle within the host and thus become dependent.

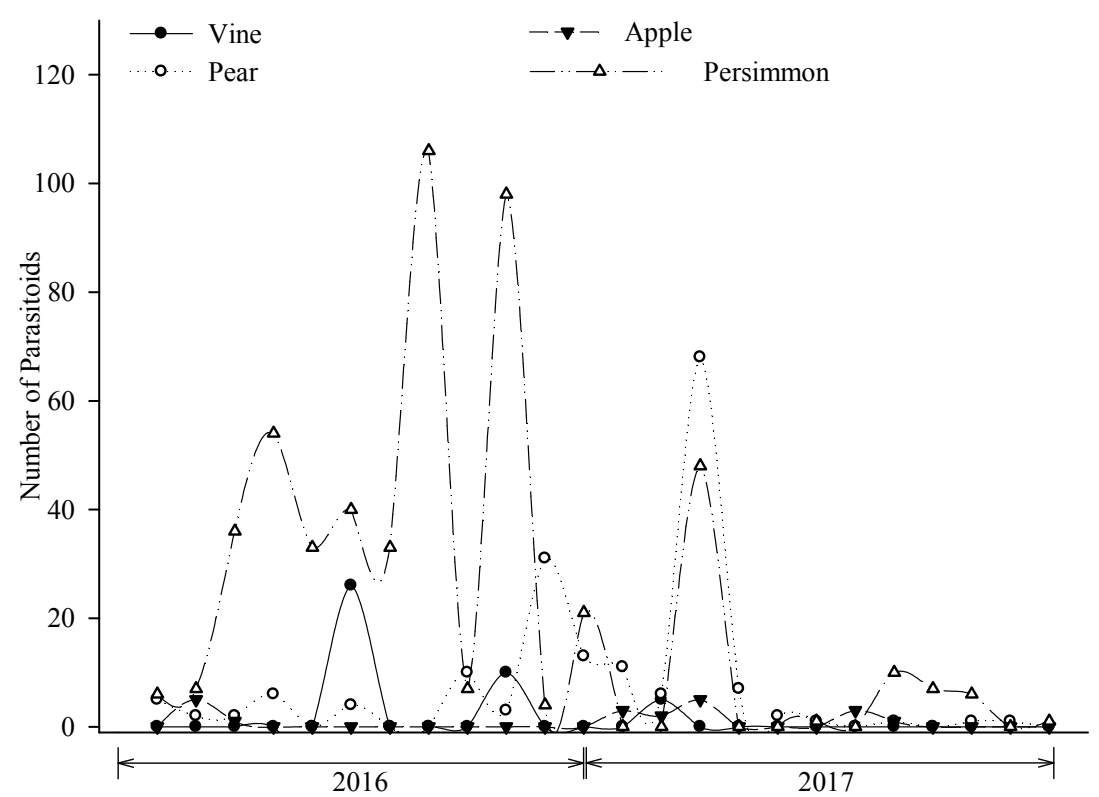

Figure 1. Population fluctuation of parasitoids in different cultures in the São Francisco Valley,

Pernambuco, Brazil

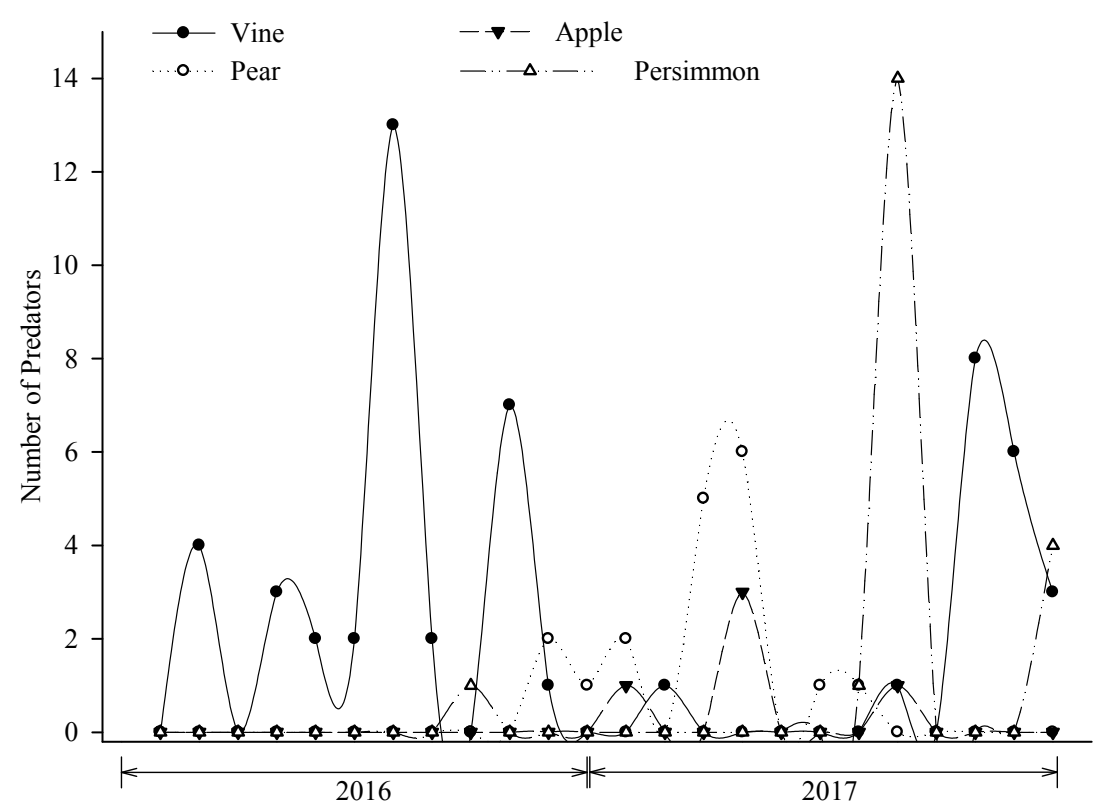

Figure 2. Population fluctuation of predators in different cultures in the São Francisco Valley, Pernambuco, Brazil

\section{Discussion}

For the success of agricultural pest control by biological control, the effectiveness of associated natural enemies is crucial (Menezes et al., 2017). The parasitoid C. perminutus is one of these enemies, which was recently recorded parasitizing Pseudococcidae naturally in the São Francisco Valley (Fernandes et al., 2016). Identify the presence of natural enemies in the region is a factor that validates the mass application of these organisms in 
production scale, since the adaptation of these insects is already well defined, that is, the use of natural enemies has a high success in relation to its efficiency.

In a study conducted for sixteen years, natural enemies associated with Pseudococcus sp. and Paracoccus abnormalis, in vine, were collected and reared. Accounting for seven parasitoid species, among which, Anagyrus sp., Gyranusoidea sp. and Coccophagus sp., and four predator species, among which, C. montrouzieri and Diadiplosis sp. (Charles, Bell, Lo, Cole, \& Chhagan, 2012). Among these natural enemies with high potential for biological control, rearing in New Zealand, there are also species found in the São Francisco Valley, which may have an important parasitism and predation relationship, such as Anagyrus sp., G. indica, C. montrouzieri., and D. multifila, which may be used in biological control programs in integrated management of mealybug pests. The similarity between the climatic conditions of New Zealand and Brazil indicates the success in applying these organisms not only to fruit production in the São Francisco Valley, but in all cultures where these pests occur throughout the country.

About thirty-nine parasitoid and forty-two predator species of Maconellicoccus hirsutus (Chong, Aristizábal, \& Arthurs, 2015) are known in the world, with twenty-seven species in the Neotropical region (Culik et al., 2013; Chong et al., 2015), considering that Brazil is one of the richest countries in biodiversity, both in fauna and flora. In biological control programs in various countries, several species of natural enemies have already been used, such as the predatory ladybug, $C$. montrouzieri Mulsant (Coleoptera: Coccinellidae) and the parasitoids $A$. kamali Moursi and G. indica Shafee, Alam \& Agarwal (Hymenoptera: Encyrtidae) (Culik et al., 2013; Chong et al., 2015), all found in the present study, evidencing the possibility of applying a clean, efficient and productive control, as occurs when using natural enemies. Once again, São Francisco Valley shows a high perspective for the use and scale production of these organisms.

In Israel, which also has a semiarid climate, fourteen species of natural enemies are associated with P. solenopsis; however, Aenasius arizonensis (Girault) (Hymenoptera: Encyrtidae) stood out. This parasitoid has controlled the population density of the mealybug in question in that country (Spodek et al., 2018), making it potentially usable at São Francisco Valley because of the high adaptability of the genus Aenasius sp. in the region. Some insects may become more adapted to a given region, which indicates the need to continue the current work with more research to determine which natural enemies are most efficient in applied biological control and, therefore, develop their potential. Brazil, especially the Northeast region, promote greater development of the life cycle of insects, given their favorable climatic conditions.

Biological control is the most appropriate method to control mealybugs, because these pests have a high diversity of hosts, easily disperse to various regions, have as main characteristic the presence of wax on their body, which prevents full penetration of chemical compounds, and protect themselves in plant regions that are difficult to access by chemical applications (Peronti et al., 2016).

Reports of predators and parasitoids controlling mealybug populations in Brazil are common. Aphelinidae, Encyrtidae, Eulophidae, Eupelmidae, Pteromalidae, Signiphoridae, Azotidae, Mymaridae, and Platygastridae stand out among the main parasitoid families, and Chrysopidae, Cecidomyiidae, Drosophilidae, Syrphidae, and Coccinellidae among the main predator families, in which Coccinellids of the genus Cryptolaemus, Scymnus, Coccidophilus, Azya, Cycloneda, Chilocorus, Exoplectra, Harmonia, Tenuisvalvae, and Pentilia are commonly found associated with mealybug species (Cruz, 2018).

Less frequently, stinkbugs predators of mealybugs showed good responses for predation, satisfactorily reducing the population of Pseudococcidae and selective insecticides (Kitherian et al., 2018). In addition to insects, Rhabditida nematodes are entomopathogenic and have also been studied for applications in the control of mealybugs (Platt, Stokwe, \& Malan, 2018).

Parasitoids have a higher preference for mealybugs in later stages of their life cycle, showing little or no parasitic activity on younger mealybugs in their first instars, as observed by Silva, Garcia, and Botton (2017) on Blepyrus clavicornis, and also reported for Anagyrus sp., Aenasius bambawalei and Aenasius vexans. The biological control using the parasitoid Anagyrus kamali has reduced the mealybug populations, in combination with other control methods (Negrini, Morais, Batista, \& Chagas, 2018). This is a fundamental factor for integrated pest management, using all available resources when necessary, in a sustainable manner, preserving the entire environment and natural resources.

Parasitoids are most commonly used in biological control since they are generally pest specialists and are always associated with their host, unlike predators, which are generalists. They have great potential for reproduction and rearing provided that the researcher has a thorough knowledge of the specific characteristics of the natural enemy and its pest; thus, there will be successful management (Bostanian et al., 2012). 
Anyway, the use of predators and parasitoids still needs to be studied and disseminated in agriculture, mainly due to the countless benefits that integrated pest management brings, protecting nature and all its resources that are fundamental to human existence.

\section{Conclusions}

The genera Anagyus and Aprostocetus and the species Coccidoxenoides perminutus are parasitoids with high potential for biological control of mealybugs in this region.

Anagyrus kamali is a species of parasitoid that stood out in the study, being the greatest potential for sequential work, as a species of predator Diadiplosis multifila in mealybug statistics in the Brazilian Semiarid.

\section{References}

Araújo, E. L., Fernandes, E. C., Silva, R. I. R., Ferreira, A. D. C. L., \& Costa, V. A. (2015). Parasitoides (Hymenoptera) de moscas-das-frutas (Diptera: Tephritidae) no Semiárido do Estado do Ceará, Brasil. Revista Brasileira de Fruticultura, 37(3), 610-616. https://doi.org/10.1590/0100-2945-188/14

Beltrà, A., Addison, P., Ávalos, J. A., Crochard, D., Garcia-Marí, F., Guerrieri, E., ... Soto, A. (2015) Guiding Classical Biological Control of an Invasive Mealybug Using Integrative Taxonomy. PLoS ONE, 10(6), 1-14. https://doi.org/10.1371/journal.pone.0128685

Bertin, A., Bortoli, L. C., Botton, M., \& Parra, J. R. P. (2013). Host Plant Effects on the Development, Survival, and Reproduction of Dysmicoccus brevipes (Hemiptera: Pseudococcidae) on Grapevines. Entomological Society of America, 106(5), 604-609. https://doi.org/10.1603/AN13030

Bostanian, N. J., Vincent, C., \& Isaacs, R. (2012). Arthropod management in vineyards. Dordrecht: Springer. https://doi.org/10.1007/978-94-007-4032-7

Bouček, Z., \& Heydon, S. L. (1997). Pteromalidae: Annotated keys to the genera of Nearctic Chalcidoidea (Hymenoptera). Ottawa: NRC Research Press.

Bugila, A. A. A., Franco, J. C., Silva, E. B., \& Branco, M. (2014). Defense Response of Native and Alien Mealybugs (Hemiptera: Pseudococcidae) Against the Solitary Parasitoid Anagyrus sp. nr. pseudococci (Girault) (Hymenoptera: Encyrtidae). Journal of Insect Behavior, 27(1), 439-453. https://doi.org/10.1007/ s10905-014-9440-X

Charles, J. G., Bell, V. A., Lo, P. L., Cole, L. M., \& Chhagan, A. (2012). Mealybugs (Hemiptera: Pseudococcidae) and their natural enemies in New Zealand vineyards from 1993-2009. New Zealand Entomologist, 1(1), 84-91. https://doi.org/10.1080/00779962.2010.9722195

Chong, J. H., Aristizábal, L. F., \& Arthurs, S. (2015). Biology and management of Maconellicoccus hirsutus (Hemiptera: Pseudococcidae) on ornamental plants. Journal of Integrated Pest Management, 6(1), 1-14. https://doi.org/10.1093/jipm/pmv004

Cruz, M. A. (2018). Inimigos naturais de cochonilhas (Hemiptera: Sternorrhyncha: Coccoidea) associadas a plantas de importância econômica no estado de São Paulo. Dissertação (Mestrado em Agronomia, Entomologia Agrícola, Universidade Estadual Paulista, Faculdade de Ciências Agrárias e Veterinárias, Jaboticabal, Brazil). Retrieved from https://repositorio.unesp.br/bitstream/handle/11449/153546/cruz_ma_ me_jabo.pdf? sequence $=4$

Culik, M. P., Fornazier, M. J., Martins, D. S., Zanuncio Jr., J. S., Ventura, J. A., Peronti, A. L. B. G., \& Zanuncio, J. C. (2013). The invasive mealybug Maconellicoccus hirsutus: lessons for its current range expansion in South America and invasive pest management in general. Journal of Pest of Science, 86(1), 387-398. https://doi.org/10.1007/s10340-013-0512-z

Darling, D. C. (1997). Perilampidae: Annotated keys to the genera of Nearctic Chalcidoidea (Hymenoptera). Ottawa: NRC Research Press.

Fernandes, M. H. A., Oliveira, J. E. M., Costa, V. A., \& Menezes, K. O. (2016). Coccidoxenoides perminutus parasitizing Planococcus citri on vine in Brazil. Ciência Rural, 46(1), 1130-1133. https://doi.org/ $10.1590 / 0103-8478 \mathrm{cr} 20150357$

Kitherian, S., Kumar, V., Banu, N., Avery, P. B., Radhika, A., Mckenzie, C. L., \& Osborne, L. S. (2018). Predation potential of Rhynocoris marginatus (Hemiptera: Reduviidae) against three mealybug species of agricultural importance. Applied Entomology and Zoology, 1(1), 8. https://doi.org/10.1007/s13355018-0588-2 
Lima, M. S., Melo, J. W. S., \& Barros, R. (2016). Biology of Zagreus bimaculosus Mulsant (Coleoptera: Coccinellidae), a Predator of Ferrisia dasylirii (Cockerell) (Hemiptera: Pseudococcidae). The Coleopterists Bulletin, 70(2), 314-320. https://doi.org/10.1649/0010-065X-70.2.314

Menezes, K. O., Fernandes, M. H. A., Paz, H. H. R., Souza, A. M., Torres, J. B., \& Oliveira, J. E. M. (2017). Parasitismo da cochonilha-farinhenta Planococcus citri (Hemiptera: Pseudococcidae) por Coccidoxenoides perminutus (Hymenoptera: Encyrtidae). Revista Ceres, 64(5), 486-491. https://doi.org/10.1590/0034-737X 201764050005

Negrini, M., Morais, E. G. F., Batista, J. S. R., \& Chagas, E. (2018). A. Population fluctuations in the pink hibiscus mealybug and its natural enemies in Annona squamosa (Annonaceae) in Roraima, Brazil. Acta Amazonica, 48(1), 28-31. https://doi.org/10.1590/1809-4392201701131

Noyes, J. S. (1980). A review of the genera of Neotropical Encyrtidae (Hymenoptera: Chalcidoidea). Bulletin of the British Museum (Natural History) (Entomology), 41(1), 107-253.

Noyes, J. S. (2017). Universal Chalcidoidea Database. Retrieved from http://www.nhm.ac.uk/chalcidoids

Noyes, J. S., \& Hayat, M. (1994). Oriental mealybug parasitoids of the Anagyrini (Hymenoptera: Encyrtidae). Oxon: CAB International.

Peronti, A. L. B. G., Martinelli, N. M., Alexandrino, J. G., Marsaro Junior, A. L., Penteado-Dias, A. M., \& Almeida, L. M. (2016). Natural enemies associated with Maconellicoccus hirsutus (Hemiptera: Pseudococcidae) in the state of São Paulo, Brazil. Florida Entomologist, 99(1), 20-25. https://doi.org/10.1653/024.099.0105

Platt, T., Stokwe, N. F., \& Malan, A. P. (2018). Potential of Local Entomopathogenic Nematodes for Control of the Vine Mealybug, Planococcus ficus. South African Journal for Enology and Viticulture, 39(2), 8. https://doi.org/10.21548/39-2-3158

Rueda, L. M., \& Axtell, R. C. (1985). Guide to common species of pupal parasites (Hymenoptera: Pteromalidae) of the house fly and other muscoid flies associated with poultry and livestock manure. Technical Bulletin 278. Raleigh: North Carolina Agricultural Research Service.

Schauff, M. E. (1997). Eulophidae: Annotated keys to the genera of Nearctic Chalcidoidea (Hymenoptera). Ottawa: NRC.

Silva, V. P., Garcia, M., \& Botton, M. (2017). Biology of Blepyrus clavicornis (Compere) (Hymenoptera: Encyrtidae), a parasitoid of Pseudococcus viburni (Signoret) (Hemiptera: Pseudococcidae). Revista Brasileira de Entomologia, 61(1), 257-261. https://doi.org/10.1016/j.rbe.2017.05.003

Silveira Neto, S., Nakano, O., Barbin, D., \& Villa Nova, N. A. (1976). Manual de ecologia dos insetos (1st ed.). Piracicaba: Agronômica Ceres.

Spodek, M., Ben-Dov, Y., Mondaca, L., Protasov, A., Erel, E., \& Mendel, Z. (2018). The cotton mealybug, Phenacoccus solenopsis Tinsley (Hemiptera: Pseudococcidae) in Israel: pest status, host plants and natural enemies. Phytoparasitica, 1(1), 1-11. https://doi.org/10.1007/s12600-018-0642-1

Tena, A., Nieves, E., Herrero, J., \& Urbaneja, A. (2017). Defensive behaviors of the new mealybug citrus pest, Delottococcus aberiae (Hemiptera: Pseudococcidae), against three generalist parasitoids. Journal of Economic Entomology, 1(1), 1-7. https://doi.org/10.1093/jee/tox307

Woolley, J. B. (1997). Aphelinidae. Annotated keys to the genera of Nearctic Chalcidoidea (Hymenoptera). Ottawa: NRC Research Press.

\section{Copyrights}

Copyright for this article is retained by the author(s), with first publication rights granted to the journal.

This is an open-access article distributed under the terms and conditions of the Creative Commons Attribution license (http://creativecommons.org/licenses/by/4.0/). 